\title{
Regional Sustainable Development Strategies in Russia: the Case of the Volga Region
}

\author{
Sergey Kirillov ${ }^{1}$, Sergey Nikonorov ${ }^{2}$ and Alla Pakina ${ }^{1}$
}

\begin{abstract}
In the context of reduced revenues from raw materials exports, the policy of sanctions and restrictions on access to capital and technologies, Russia faces an acute problem of finding new models of economic development. As world experience shows, economic growth cannot resume simultaneously throughout the country, it will inevitably be concentrated in specific regions - points of growth. Since the Federal government do not present a convincing strategy, some regions take the initiative and build their own development strategies. In this regard, the experience of the Volga region with a developed economy, the powerful drivers of growth, and large differences in social parameters is quite interesting. The main development goals were indicated in the Strategy of Privolzhsky Federal district's development up to 2020. We analyzed them on the example of 7 subjects of Federation. Despite ambitious plans, the negative dynamics of many indicators remains. The growth of GRP has not reached the planned values, and social indicators continue to decline: there is a migration outflow of population and a decrease in natural population growth. Analysis of the each region's strategies showed that there are significant risks of development, the overcoming of which requires non-trivial decisions of regional governments.
\end{abstract}

Keywords: development strategies, growth points, regional governments, sustainable development, social risks

\section{Introduction}

In the context of reduced revenues from raw materials exports, the policy of sanctions and restrictions on access to capital and technologies, Russia faces an acute problem of finding new models of economic development (Kirillov et al., 2018). As it is shown in a number of works, modernization requires such conditions as a high concentration of the population and high quality of life, quite developed entrepreneurial infrastructure (Sibirskaya et al. 2015), sufficient prerequisites for diffusion of innovations (Malysheva et al., 2016), and low institutional barriers (Parakhina et al., 2015). In addition, regional development strategies usually intensified in the post-crisis periods (Zubarevich, 2017). First period in modern Russia was the global crisis of 2008-2009, when the federal and regional governments work on regional strategies was intensified significantly. The next important stage of regional strategies development in Russia was 2014, when the geopolitical picture of the world was reshaped due to the well-known events. An active rethinking of the results of previous stages of development and the formation of a forecast for the near and distant periods, taking into account global challenges from 2015 in Russia, began (Veselovsky et al., 2015). Currently, the Russia’s regions are mostly focused on greening their economies in accordance to global trends (Gibbs, O’Neill, 2017). However, regions in Russia feel an increased risk of dependence on the Federal center, which, on the one hand, has limited resources to support them, and on the other hand, has no clearly defined long-term strategies. 


\section{Study Area}

As global experience shows, economic growth cannot resume simultaneously throughout the country, it will inevitably be concentrated in specific regions, which are called points of growth. One of the most developed regions of Russia is the Volga region with the status of Privolzhsky Federal district (Figure 1) is a large macroregion, which includes 15 subjects of the Federation.

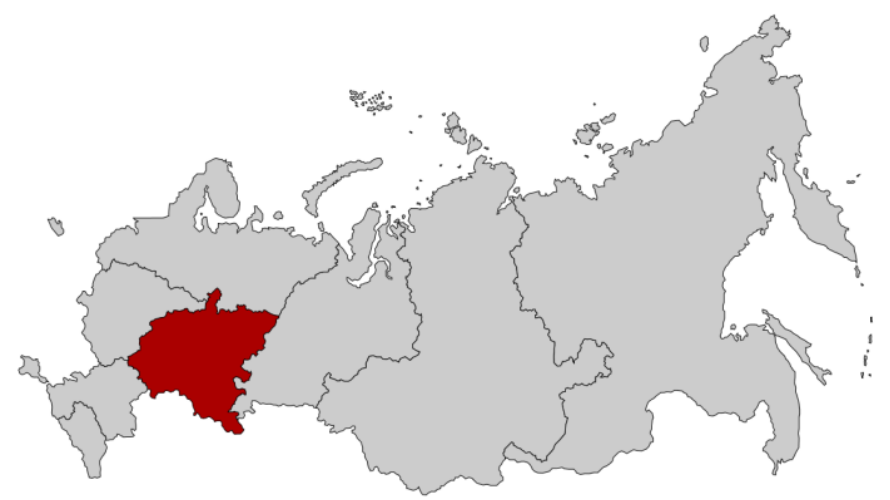

Figure 1. Privolihsky Federal district (bighlighted in red) at the map of Federal districts of Russia

The territory of the district occupies about $6 \%$ of the territory of the Russian Federation (more than 1 million $\mathrm{km}^{2}$ ), and is a home to more than $20 \%$ of the population (30 million people). It is one of the most densely populated regions of Russia. The share of the district in the all-Russian GDP exceeds 15\%. The district occupies a leading position among all districts of the Russian Federation, conceding only to the Central district, where the most part of GRP is provided by Moscow city (Figure 2).

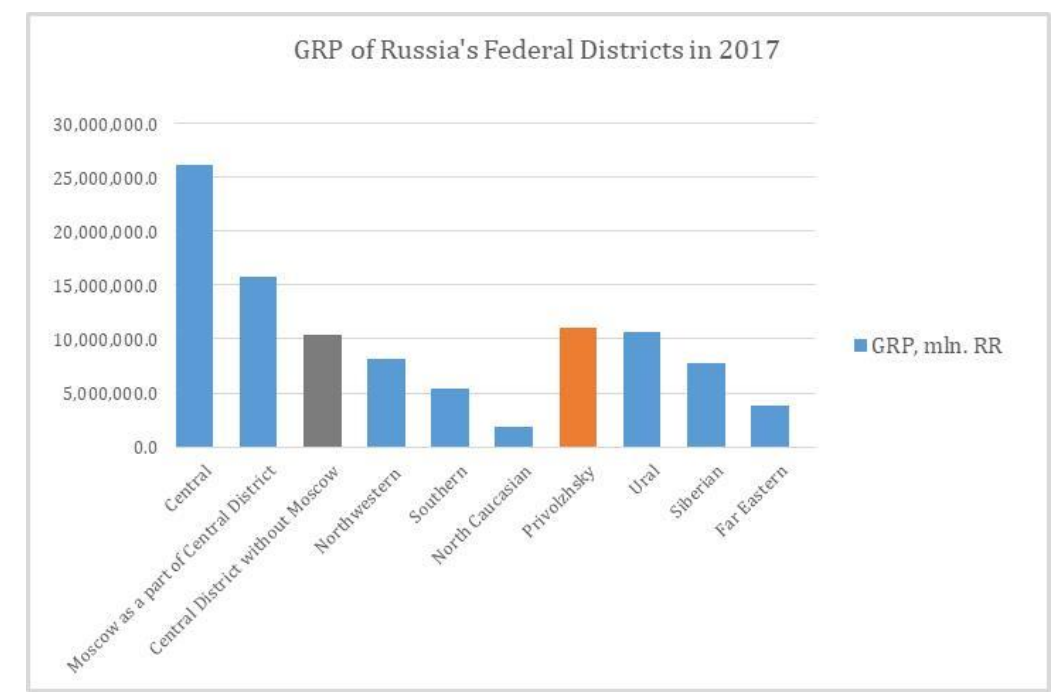

Figure 2. GRP of Russia's Federal districts in 2017 
Due to the high importance of the district to accelerate the development of the whole country the Strategy of Privolzhsky Federal district's social-economic development up to 2020, was developed in 2011 and approved by the Order of the Government of the Russian Federation of February 7, 2011 N165-p (The strategy ...). The Order particularly fixed the obligation of public authorities of subjects of the Russian Federation to be guided by provisions of the Strategy to develop their regional target programs and other program documents. The main development goals, indicated in the Strategy of Privolzhsky Federal district's development up to 2020, are covering all the sectors and identify specific criteria. We analyzed their implementation into practice on the example of 7 subjects of Federation, belonging to the district: Republic Mary El, Republic of Tatarstan and Udmurt Republic, and 4 regions (in Russia they are called oblast): Nizhny Novgorod, Samara, Saratov and Ulyanovsk (Figure 3).

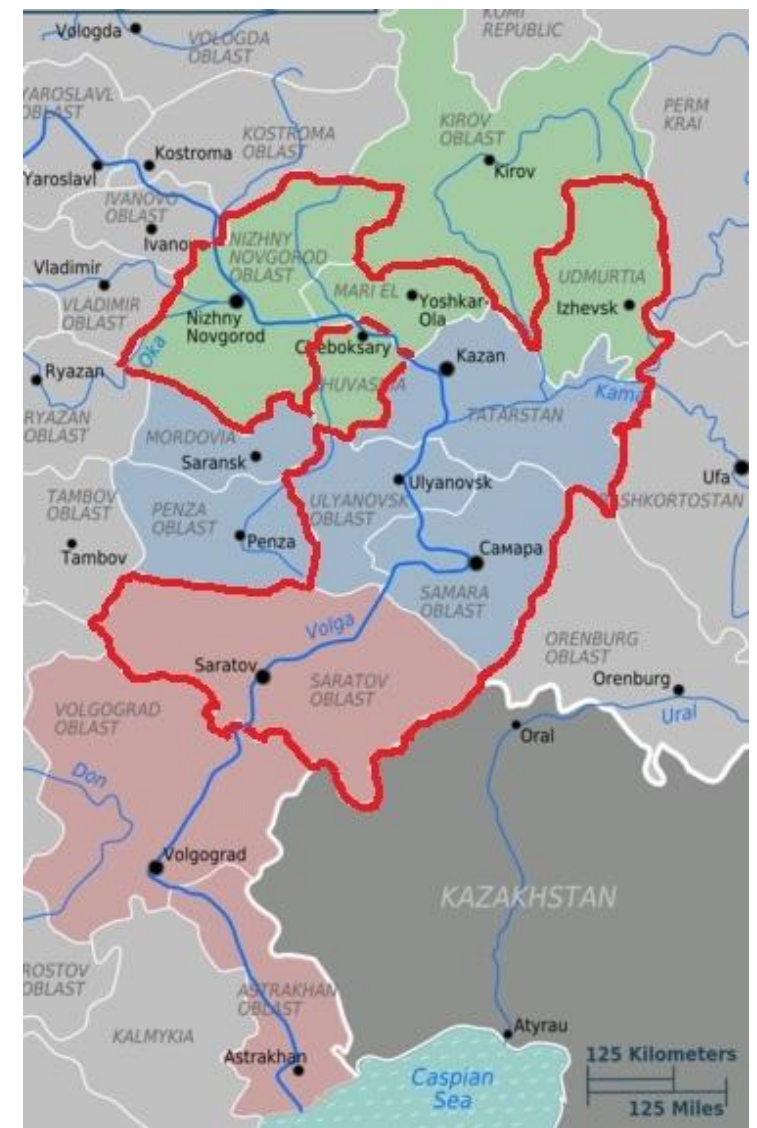

Figure 3. Subjects of the Federation included in the research region (within the red line border)

Analysis of traditional indicators of economic development, such as GRP and the share of industrial production and the agricultural sector show that in the period after 2014 most regions experienced the decline in growth rates. Economic development's indicators defined in the Strategy was not achieved in any of the Volga regions, largely 
due to the sanctions policy of western countries. At the same time, we can state that some indicators show the possibility to improve one's positions in the near future. During the period 2014-2017, the GRP volume index, as a percentage to the previous year, decreased in most of the considered regions. Growth was recorded only in the Republic of Tatarstan, Saratov and Ulyanovsk regions. At the same time, GRP decline in Tatarstan was noted only in 2015, and in subsequent years there was a slight but stable growth. In the rest of the regions, growth slowed throughout the period, and by 2017 there was small growth in the Saratov and Ulyanovsk regions (Table 1).

Table 1. Dynamics of indicators of economic development in the regions of the Privolzhsky Federal district in the period 2014-2017

\begin{tabular}{|l|c|c|c|c|c|c|}
\hline \multirow{2}{*}{ Regions } & \multicolumn{2}{|c|}{$\begin{array}{c}\text { GRP volume } \\
\text { index, \% to the } \\
\text { previous year }\end{array}$} & \multicolumn{2}{c|}{$\begin{array}{c}\text { The industrial } \\
\text { production index in \% } \\
\text { to the previous year }\end{array}$} & $\begin{array}{c}\text { Agricultural } \\
\text { production, \% of the } \\
\text { previous year }\end{array}$ \\
\cline { 2 - 7 } & 2014 & 2017 & 2014 & 2017 & 2014 & 2017 \\
\hline Republic of Mari El & 106,0 & 101,6 & 113,6 & 104,8 & 115,9 & 100,1 \\
\hline Republic of Tatarstan & 102,1 & 102,8 & 101,3 & 101,8 & 102,9 & 105,2 \\
\hline Udmurt Republic & 101,0 & 99,4 & 99,2 & 98,3 & 112,4 & 100,3 \\
\hline Nizhny Novgorod region & 102,9 & 102,0 & 100,6 & 105,0 & 102,9 & 100,3 \\
\hline Samara region & 104,2 & 100,8 & 99,4 & 102,5 & 103,8 & 101,8 \\
\hline Saratov region & 100,3 & 102,1 & 107,6 & 105,0 & 107,1 & 105,0 \\
\hline Ulyanovsk region & 100,5 & 101,5 & 102,9 & 107,0 & 100,9 & 106,5 \\
\hline
\end{tabular}

Source: http://www.gks.ru/

Thus, we can be state that in general the pace of development reflected pessimistic scenarios. For example, in one of the considered regions - the Udmurt Republic - the Strategy outlined plans to achieve the GRP value of 575 billion roubles by 2017 . The real volume of GRP amounted to 556190 million roubles. Taking into account that forecast estimates were made in current prices, the inflation component could adjust them downward. In contrast to neighbourhood the Republic of Tatarstan has more sustainable development because of more powerful regional elites (Yakovlev et al., 2017) and a longterm forecast development (Nagimov et al., 2018).

\section{Development Strategy of the Privolzhsky Federal District}

In general, the Strategy of the Privolzhsky Federal district (2011) defines the main directions, mechanisms and tools for achieving the strategic development goals of the Volga region for the period up to 2020 and is focused on the implementation of measures to overcome the main problems. The most important of that problems is an exhaustion of the current model of economic development, based on forced increase in fuel and raw materials exports. Given that the important task of the Volga region is to establish its role as one of the Russian leaders in innovative technological development, an indicator of such development may be a decrease in the share of the extractive industry and the accelerated development of manufacturing industries. Today the regions of the Privolzhsky Federal district show a relatively similar trend in manufacturing industries and different trends in mining industry (Table 2). 
The share of the extractive industry is declining in almost all the regions (except for a slight increase in the Saratov region), in accordance with the provisions of the Strategy, and the share of the manufacturing industry has multidirectional trends, changing in some cases to decline (in Tatarstan, Mari El and Ulyanovsk region).

Table 2. Dynamics of production indices in the regions of the Privolzhsky Federal district in the period 2015-2018

\begin{tabular}{|l|c|c|c|c|}
\hline \multirow{2}{*}{ Regions } & \multicolumn{2}{|c|}{$\begin{array}{c}\text { Index of production in } \\
\text { mining sector, \% to the } \\
\text { previous year }\end{array}$} & $\begin{array}{c}\text { Index of production in } \\
\text { manufacturing industry, \% to } \\
\text { the previous year }\end{array}$ \\
\cline { 2 - 5 } & 2015 & 2018 & 2015 & 2018 \\
\hline Republic of Mari El & 94,2 & 77,3 & 110,9 & 97,4 \\
\hline Republic of Tatarstan & 102,7 & 102,1 & 101,1 & 100,3 \\
\hline Udmurt Republic & 101,3 & 98,1 & 103,9 & 105,2 \\
\hline Nizhny Novgorod region & 97,6 & 91,8 & 103,1 & 103,2 \\
\hline Samara region & 104,9 & 95,6 & 96,7 & 102,7 \\
\hline Saratov region & 103,4 & 103,8 & 101,8 & 103,8 \\
\hline Ulyanovsk region & 106,0 & 96,8 & 108,3 & 101,5 \\
\hline
\end{tabular}

Source: http://www.gks.ru/

Along with purposes of innovative development, an important task is to create decent living conditions in cities and rural areas. Comparison of indicators characterizing social differences in the studied regions (Table 3) shows the relationship between the level of GRP per capita, fiscal capacity of the regions and level of HDI (Federal State Statistics Service; Goals for sustainable development).

Table 3. Indicators of social development in the regions of the Privolzhsky Federal district

\begin{tabular}{|l|c|c|c|}
\hline Regions & $\begin{array}{c}\text { GRP } \\
\text { per capita, RR }\end{array}$ & $\begin{array}{c}\text { Fiscal } \\
\text { capacity }\end{array}$ & $\begin{array}{c}\text { HDI (Human } \\
\text { Development Index) }\end{array}$ \\
\hline Republic of Mari El & 247953,7 & 0,719 & 0,835 \\
\hline Republic of Tatarstan & 543522,4 & 1,170 & 0,894 \\
\hline Udmurt Republic & 367138,2 & 0,841 & 0,862 \\
\hline Nizhny Novgorod region & 388808,8 & 0,947 & 0,854 \\
\hline Samara region & 422024,7 & 1,092 & 0,865 \\
\hline Saratov region & 270766,2 & 0,769 & 0,849 \\
\hline Ulyanovsk region & 272565,4 & 0,837 & 0,843 \\
\hline
\end{tabular}

The data (Regions of Russia) show an absolute correlation of economic indicators (GRP per capita and the Index of fiscal capacity) with the level of HDI. The negative trends are confirmed by the population data: the population decreased in most of the considered regions, with the exception of Tatarstan. So, despite the ambitious plans, the negative dynamics of many economic and social indicators remains. As GRP growth has not reached the planned values in a number of regions, social indicators continue to decline due to migration outflow of population and reduction of natural population growth (Figure 4). 
All of the characteristics mentioned above show that there are serious risks to achieve sustainable development in the regions. Since the Federal government do not present a convincing strategy, some regions take the initiative and build their own development strategies. In this regard, the experience of the Volga region with a developed economy, the powerful drivers of growth, and large differences in social parameters is quite interesting.

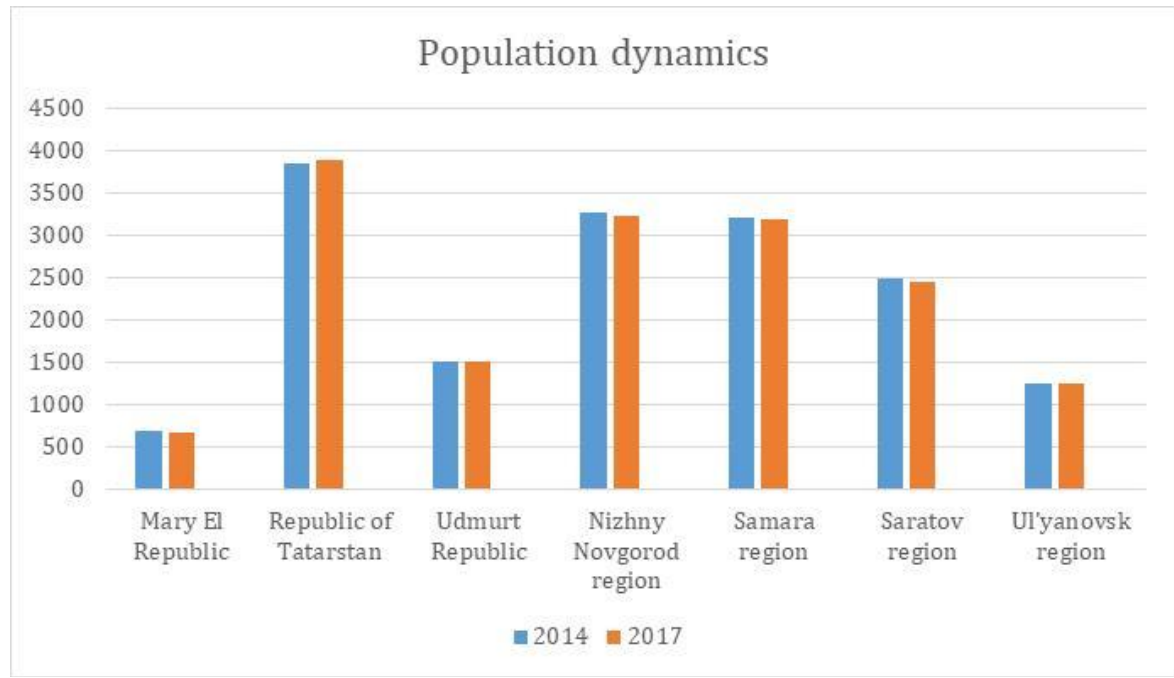

Figure 4. The population of the Volga region (thousand people)

Source: http:// www.gks.ru/bgd/ regl/B15_14p/Main.htm

As it is indicated in the Strategy of development of the Privolzhsky Federal district, the main challenge of the current moment for the district is "strengthening the global competition covering not only traditional markets of goods, capital, technologies and labor force, but also systems of national management, support of innovations, development of human potential". The second challenge is "the expected new wave of technological changes that stenches the role of innovations in socio-economic development and reduces the impact of many traditional growth drivers" (The strategy ...). In the next decade, the developed countries will move to the new technological level of economic systems based on use of the latest achievements in biotechnology, informatics and nanotechnology, including health and other social areas, so they should be the key reference points of regional strategies.

The economic development of the Volga regions, which have a diversified economic structure, is largely determined by the state of the industrial sector. Problems in the development of this sector affect the social sphere and production indicators, so the industry modernization must be a key priority of regional development's strategies. Today a transition to high-tech production is constrained by the lack of sufficient investment (Uskova et al., 2017). In this regard, the following directions can be considered as the key elements of the Volga region development strategies:

- formation of vertical integration chains of mining and processing industries, increasing 
a multiplier of added value;

- creation of conditions for increasing an industrial enterprises production, which can provide additional funds for modernization;

- implementation of regional personnel policy aimed at enhancing the internal resources of the regions to create new high-performance jobs.

Implementation of these measures is largely associated with the intensification of government efforts to stimulate industrial sector of the economy, including:

1) providing the subjects of industrial activity with preferential terms of operation, including subsidies and investment loans for the implementation of promising technological and innovative projects;

2) improvement of the existing legislation in the field of tax policy regulation and reduction of the administrative burden for the development of tax benefits, reduction of mandatory requirements and the number of verification procedures for industrial enterprises;

3) growth of cooperation between the state, industrial enterprises and educational institutions in order to improve the quality of training for innovative sectors of the economy.

In the agricultural sector, in order to stimulate investment activity and increase competitiveness, it is also necessary to continue the tax policy's optimization, in particular, the mechanism of the single agricultural tax, tax holidays, etc., which will have a positive impact on investment activity (Yurkova, Likhovtsova, 2016). When selling agricultural goods, the main tax burden should be transferred to the market entity that has a large share in the price premium on the final product, thereby stimulating direct sales and cooperation and integration ties in the agricultural sector of the Volga region (Yurkova et al., 2017). In addition, it is necessary to introduce the world practice of supporting agricultural producers, which is most acceptable to the conditions of the Volga regions.

\section{Investment Attraction of the Volga Region}

Modernization of the industrial sector is one of the main sources of Volga region's further sustainable economic development. However, the implementation of these plans should be carried out simultaneously with a number of important changes at the Federal level. Among them is the improvement of tax policy, which will overcome the technological gap between Russia and the advanced economies of the world. Investment support of most intensively developing sectors, like construction complex, on the principles of sustainable development is of great importance (Kankhva et al., 2016).

The current favorable conditions for the development of the economy ensure an investment attraction to the Volga region - a key factor of modernization. Analysis of investment potential allows us to identify leaders and outsiders among the Volga regions. Analysis of the data allows us to make a forecast on the main drivers of growth, on which the attention of both regional and federal authorities should be focused in the future. According to the data (Table 4) and the rating of the expert Agency "Expert RA" we can conclude that despite the internal socio-economic variability the Republic of 
Tatarstan and Samara region can be marked as the investment-attractive regions (Expert RA; Glazunova, Zykova 2018).

Table 4. Investments in fixed capital by subjects of Privolzhsky Federal district (in actual prices, million rubles)

\begin{tabular}{|l|c|c|c|c|c|}
\hline \multirow{2}{*}{ Regions } & \multicolumn{4}{|c|}{ Years } & \multirow{2}{*}{2016 to 2013, \% } \\
\cline { 2 - 5 } & 2013 & 2014 & 2015 & 2016 & \\
\hline Republic of Mari El & 46178 & 47228 & 40332 & 27204 & 58,91 \\
\hline Republic of Tatarstan & 525730 & 542781 & 617128 & 642494 & 122,21 \\
\hline Udmurt Republic & 82678 & 91571 & 81846 & 85406 & 103,30 \\
\hline Nizhny Novgorod region & 280884 & 276820 & 235067 & 219658 & 78,20 \\
\hline Samara region & 269737 & 321760 & 302884 & 256774 & 95,19 \\
\hline Saratov region & 125834 & 137421 & 140129 & 145157 & 115,36 \\
\hline Ulyanovsk region & 76835 & 77178 & 79461 & 68878 & 89,64 \\
\hline
\end{tabular}

\section{Realization of Russia's Development Goals in the Privolzhsky Federal District}

An important regulatory role in the Federal strategy development as a driver of regional strategies is to be played by the decree of The President of the Russian Federation of May 7, 2018, defining the national development goals for the period up to 2024. The decree determine the national development goals of the Russian Federation for the period up to 2024, including: 1) increasing the population and life expectancy to 78 years by 2024 and 80 years by 2030; 2) improving the standard of living; 3) growth of population real incomes above inflation; 4) halving poverty in the country; 5) ensuring economic growth above the world level; 6) the entry of the Russian Federation in the five largest economies in the world; 7) improving the living conditions of not less than 5 million families annually; 8) formation of mechanisms for the support of talents.

The principles mentioned above give us an idea not only about the priority directions of development, but also about the trends in the development of authorities, coordination of actions and redistribution of power between regional and federal governments and improvement of the system of indicators of its implementation. In addition, specific targets are set to achieve the spatial development of the country aimed on modernization and expansion of the main infrastructure according the plan 2024 (Table 5).

Table 5. The main directions of spatial development of Russian regions related to the subjects of the Privolzhsky Federal district

\begin{tabular}{|c|c|c|}
\hline Targets & Implementation through & Significance for the Volga regions \\
\hline \multirow[t]{2}{*}{$\begin{array}{l}\text { Development of «West - } \\
\text { East» and «North - South» } \\
\text { transport corridors }\end{array}$} & $\begin{array}{l}\text { Construction and modernization } \\
\text { of road sections related to the } \\
\text { international transport route } \\
\text { «Europe-Western China» }\end{array}$ & $\begin{array}{l}\text { - Road Shali-Bavly (Republic of } \\
\text { Tatarstan), } 325 \mathrm{~km} \\
\text { - Road Bavly-Kumertau (Republic of } \\
\text { Bashkortostan), } 290 \mathrm{~km} \\
\text { - High-speed road Moscow - Nizhny } \\
\text { Novgorod - Kazan, } 693 \mathrm{~km} \\
\end{array}$ \\
\hline & $\begin{array}{l}\text { Increase of capacities of sea ports } \\
\text { of the Russian Federation }\end{array}$ & $\begin{array}{l}\text { - Ports of the Volga-Caspian basin } \\
\text { - Formation of nodal cargo multimodal } \\
\text { transport and logistics centers }\end{array}$ \\
\hline
\end{tabular}




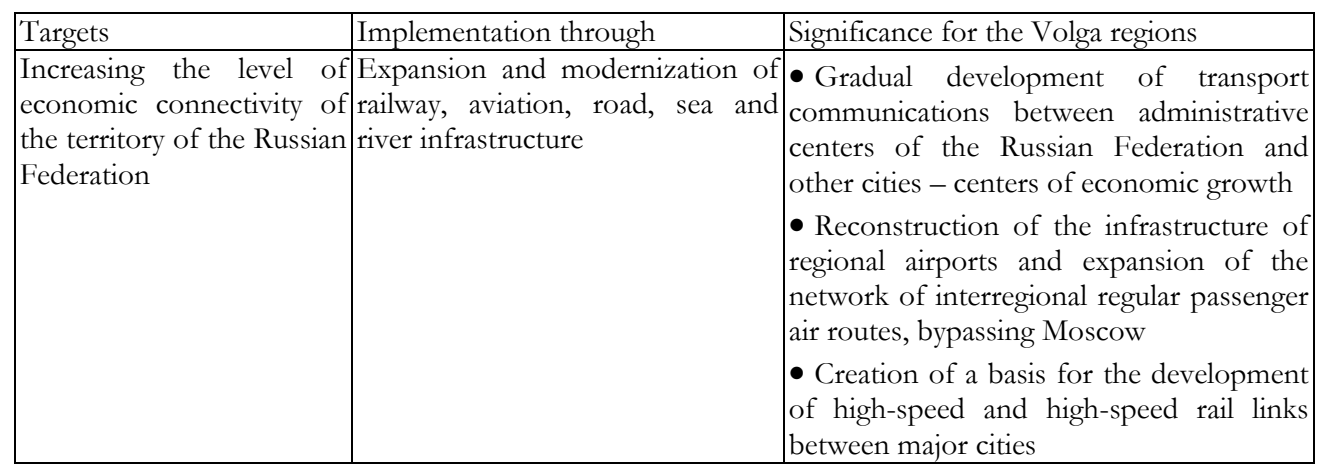

\section{Major Regional Centers}

Building the single space within the borders of the Russian Federation is the main strategy for spatial development and planning at the federal level. Since the existing programs contradict each other and cannot be the basis of regional policy, it was necessary to determine what exactly to develop: regions-megacities (agglomerations) or the whole territory. In contemporary world, cities are the drivers of the spatial development. That's why it is important to develop communication between regional centers, by passing the main centers - Moscow and St. Petersburg. This approach will strengthen the resettlement's framework, the country's connectivity, and will cause economic and other effects. Many experts note that along with the high raw material supply, the agglomeration effect is an advantage of the regions of Russia. Today, one in five Russians live in the largest cities with a million inhabitants, and this is the most educated, mobile and active part of the population (Zubarevich, 2017). Developed human capital of the largest cities has not yet become a driving force of modernization due to many barriers - infrastructure, economic, political. Gradual decentralization (centre - regions, regions - municipalities) is necessary, returning to large cities the resources and powers that have now been withdrawn from them. Without the advanced development of large cities, Russia will not be able to modernize.

Understanding of the leading role of the largest cities is reflected in the main ideas of the decree. The same ideas are present in regional strategies. The leading role in changing the spatial structure of the Volga region and Privolzhsky Federal district is assigned to 6 largest urban areas: Kazan, Nizhny Novgorod, Samara-Tolyatti, Perm, Saratov and Ufa agglomerations, each of which is home to more than 1 million people. Thus, 6 enlarged development zones are formed on the territory of the district:

1) Nizhny Novgorod (with the center in Nizhny Novgorod city), including zones of advanced economic growth with innovative, industrial (mechanical engineering, chemical, petrochemical, pharmaceutical industry, metallurgy, timber industry, etc.) and transport and logistics functions;

2) Kamsko-Vyatskaya (with the center in Perm city), including zones of the advancing economic growth with industrial (mechanical engineering, chemistry, oil refining, timber industry complex, etc.) functions;

3) Kazan (with the center in Kazan city), including zones of the advancing economic 
growth with innovative, industrial (transport mechanical engineering, aircraft construction, oil refining and petrochemistry, etc.), agro-industrial, transport and logistic functions;

4) Ufa (with the center in Ufa city), including zones of advanced economic growth with industrial (oil refining and petrochemistry, engineering, etc.), agro-industrial and touristrecreational functions;

5) Srednevolzhskaya (with the center in Samara city), including zones of the advancing economic growth with innovative, industrial (transport, aerospace, instrument-making, chemistry and petrochemistry, etc.), agro-industrial, tourist-recreational and transportlogistic functions;

6) Orenburg (with the center in Orenburg city), including zones of the advancing economic growth with industrial (gas chemistry, metallurgy, mechanical engineering), agro-industrial, transport and logistic functions.

\section{Conclusion}

The analysis of the fiscal capacity of Russian regions and cities shows that the dynamics of the budgets of urban districts is much worse than the consolidated budgets of the regions (2\% vs. 11\%) (Papenov et al., 2015). Compliance of the proportions between local and regional development must be the main principle (Pike at al., 2016). Redistribution of funds in favour of the subjects of the Federation, while urban agglomerations do not receive sufficient funds does not contribute to sustainable development. Such redistribution of funds does not allow to develop strong municipalities, in spite the cities, and especially urban agglomerations, are the key points of economic power. Thus, the modern development of Russian regions is largely hampered by the inefficient fiscal policy of the state. Regional development strategies are still determined by the Federal authorities. In this regard, the focus of regional development strategies must be shifted on the development of the largest agglomerations and the financial policies and tax instruments to ensure the implementation of these goals.

\section{Acknowledgments}

The article prepared with the financial support of the Russian Foundation for Basic Research (RFBR) grant 17-02-00773 "Theoretical and methodological foundations of sustainable development of Russian regions (on the example of the Volga region)".

\section{References}

Expert RA. Available at: http://raexpert.ru/ratings/regions/2017/att1 [Accessed 12 Mart 2019]. (in Russian)

Federal State Statistics Service. Available at: http://www.gks.ru/wps/wcm/connect/rosstat main/rosstat /ru/statistics/accounts/\# [Accessed 02 Mart 2019]. (in Russian)

Gibbs, D., \& O’Neill, K. (2017). Future green economies and regional development: a research agenda. Regional Studies, 51(1), 161-173. 
Glazunova, E. Z., \& Zykova, E. N. (2018). Comparative analysis of the investment attractiveness of the regions of the Privolzhsky Federal district. Vector Economy, 1(19), 31. (in Russian)

Goals for sustainable development. Analytical report. Available at: http://ac.gov.ru/files/publication/a/11068.pdf (in Russian)

Kankhva, V., Uvarova, S., \& Belyaeva, S. (2016). Development of the scientific and methodological assessment tools of sustainability of the investment and construction complex in Russia and its structural elements in terms of organizational and economic changes. Procedia Engineering, 165, 1046-1051.

Kirillov, S., Nikonorov, S., \& Pakina, A. (2018). Modern methods of the regional development's sustainability assessment and their approbation - the Republic of Tatarstan, for example. In International Scientific Conference "Competitive, Sustainable and Secure Development of the Regional Economy: Response to Global Challenges" (CSSDRE 2018). Atlantis Press, 297-300.

Malysheva, T. V., Shinkevich, A. I., Kharisova, G. M., Nuretdinova, Y. V., Khasyanov, O. R., Nuretdinov, I. G., ... \& Kudryavtseva, S. S. (2016). The sustainable development of competitive enterprises through the implementation of innovative development strategy. International Journal of Economics and Financial Issues, 6(1), 185-191.

Nagimov, A. R., Akhmetshin, E. M., Slanov, V. P., Shpakova, R. N., Solomonov, M. P., \& Il'yaschenko, D. P. (2018). Foresight technologies in the formation of a sustainable regional development strategy. European Research Studies Journal, 21(2), 741-752.

Papenov, K. V., Nikonorov, S. M., \& Zemskova, O. V. (2015). Social, environmental, and economic problems of megacities. Studies on Russian Economic Development, 26(5), 499-503.

Parakhina, V. N., Boris, O. A., \& Midler, E. A. (2015). Evaluation of innovative regional development Russia. Asian Social Science, 11(5), 201.

Pike, A., Rodríguez-Pose, A., \& Tomaney, J. (2016). Local and regional development. Routledge.

Regions of Russia. Socio-economic indicators (2018). Rosstat. (in Russian)

Sibirskaya, E., Yarnykh, E., Eldyaeva, N., Dubrova, T., \& Oveshnikova, L. (2015). Strategy of systemic development of entrepreneurial infrastructure of regional economy. European Research Studies, 18(3), 239.

The strategy of socio-economic development of the Privolzhsky Federal district until 2020. Approved by the Order of the Government of the Russian Federation of February 7, 2011 N 165-p. Available at: https://rg.ru/2011/02/22/privoljye-site-dok.html (in Russian)

Uskova, T. V., Lukin, E. V., Melnikov, A. E., \& Leonidova, E. G. (2017). Problems of development of the industrial sector of the economy of the old industrial regions of Russia. Economic and social changes: facts, trends, forecast, 10(4), 62-77. (in Russian)

Veselovsky, M. Y., Gnezdova, J. V., Romanova, J. A., Kirova, I. V., \& Idilov, I. I. (2015). The strategy of a region development under the conditions of new actual economic. Mediterranean Journal of Social Sciences, 6(5), 310.

Yakovlev, A. A., Freinkman, L. M., Makarov, S. A., \& Pogodaev, V. S. (2017). Consolidation of elites as a prerequisite for the formation of a new regional model of economic development: the experience of the Republic of Tatarstan. Higher School of Economics. (in Russian)

Yurkova, M. S., \& Likhovtsova E. A. (2016). The influence of state policy on the investment attractiveness of the agro-industrial sector and the main trends in the development of the agricultural sector of Russia. Scientific Review: Theory and Practice, 1, 60-71. (in Russian)

Yurkova, M. S., Serdobintsev, D. V., Likhovtsova, E. A., \& Kotar O. K. (2017). Prospects for investment development of the agricultural sector of the Volga region. Agrarian scientific journal, 2, 94-100. (in Russian)

Zubarevich, N. V. (2017). Development of the Russian space: barriers and possibilities of regional policy. World of New Economy, 2, 46-57. (in Russian) 